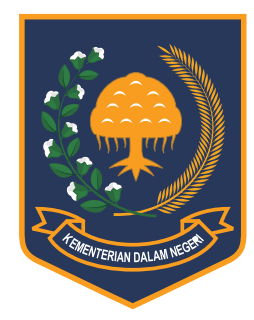

\title{
JURNAL BINA PRAJA
}

e-ISSN: 2503-3360 | p-ISSN: 2085-4323

Accreditation Number

21/E/KPT/2018

http://jurnal.kemendagri.go.id/index.php/jbp/index

\section{Raising Local Fiscal AUtonomy In THE LOCAL AUTONOMY MANAGEMENT (A STUDY IN BOGOR REGENCY)}

\author{
Anselmus Tan ${ }^{1, *}$ \\ ${ }^{1}$ Ministry of Home Affairs of the Republic of Indonesia \\ Jalan Merdeka Utara Nomor 7 Jakarta Pusat
}

Received: 10 March 2020; Accepted: 9 May 2020; Published online: 28 May 2020

DOI: $10.21787 / \mathrm{jbp} .12 .2020 .53-63$

\begin{abstract}
Local fiscal autonomy of Bogor Regency is still low, due to the low contribution of local own revenue to total local revenues. This fact has implications for the high local financial dependence on fiscal transfer from the central government, so that the Bogor Regency government is not yet autonomous in financing local development programs. This research aims to obtain rational knowledge about the effects of fiscal decentralization implementation and indirect local tax management on local fiscal autonomy. The research used a descriptive method with a qualitative approach, so that it can explain data and information obtained from observation, interview, and focus group discussion. The research concludes that the prospect of raising local fiscal autonomy is determined by the accuracy of fiscal decentralization implementation and the effectiveness of indirect local tax management. The accuracy of fiscal decentralization implementation requires the central government policy in the assignment of taxes and revenue sources to local government must be commensurate with the assignment of expenditure responsibilities to local government. The effectiveness of indirect local tax management requires that local government efforts to increase indirect local tax revenues must precisely determine the increase of revenue targets according to the results of econometric analysis of Gross Domestic Regional Product (GDRP) on certain sectors, improving the ability of local tax apparatus, and improving the obedience of indirect local taxpayer.
\end{abstract}

Keywords: Local Fiscal Autonomy, Fiscal Decentralization Implementation, Indirect Local Tax Management.

\section{INTRODUCTION}

Indonesia is a unitary state with a decentralized system. Decentralization is the transfer of government functions from the central government to local governments to regulate and manage government functions in accordance with the local community interests. Theoretically, types of decentralization are administrative, political, and fiscal (Treisman, 2007 , p. 28). In implementing decentralization principle, provinces, regencies, and cities are formed as autonomous regions.

To realize the effectiveness of local autonomy management, each autonomous region must have local revenue sources to finance local development programs to provide of public goods and services for the community. Generally, there are seven basic elements of local autonomy, namely: authority, institutions, financial resources, personnel, representatives, public services, and supervision (Suwandi, 2002, p. 7).

Local revenue sources as regulated in Law No. 23 of 2014 on Local Government, consist of: (a) local own revenues (local taxes; local levies; results of the management of separated local assets; and other legal local own revenues); (b) transfer funds (from central government and inter-regional); and (c) other legal local revenues. Based on these local revenue sources, local own revenues are local financial sources that are managed and used autonomously by the local government. In this case, local own revenues are a parameter to measure local fiscal autonomy. This is consistent with the expert's statement that local fiscal autonomy is the ability of local governments to finance local government expenditure responsibilities

\footnotetext{
* Corresponding Author

Phone : +62811 177596

Email : anselmustan@yahoo.com
} 
Table 1.

The Profile of Bogor District APBD of 2016

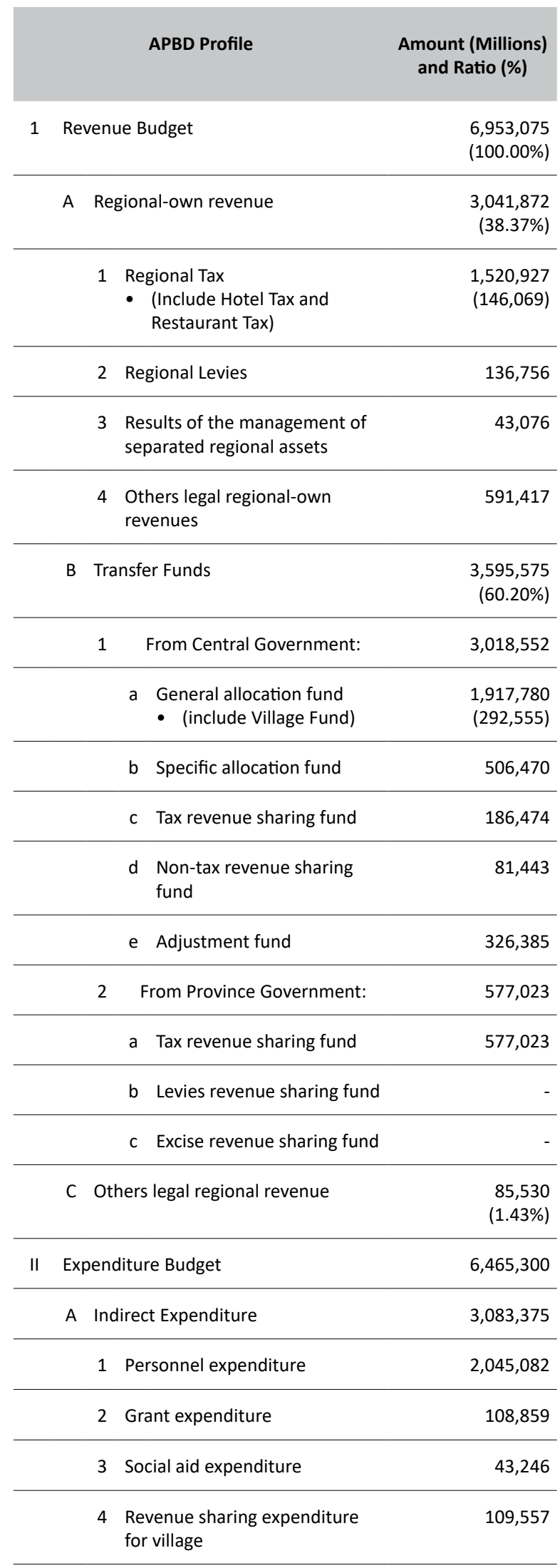

\begin{tabular}{|c|c|c|c|}
\hline \multicolumn{3}{|r|}{ APBD Profile } & \multirow{2}{*}{$\begin{array}{l}\text { Amount (Millions) } \\
\text { and Ratio (\%) } \\
763,780\end{array}$} \\
\hline & & 5 Financial aid expenditure & \\
\hline & & 6 Contingency expenditure & 12,851 \\
\hline & B & Direct Expenditure & $3,381,925$ \\
\hline & & 1 Personnel expenditure & 485,321 \\
\hline & & 2 Goods and services expenditure & $1,354,774$ \\
\hline & & 3 Capital expenditure & $1,541,830$ \\
\hline III & Fina & ancing Budget & \\
\hline & A & Financing Revenue: & $1,350,398$ \\
\hline & & 1 Budget surplus of last year & $1,350,398$ \\
\hline & & $\begin{array}{l}2 \text { Reacceptance of investment } \\
\text { funds from Regional Owned } \\
\text { Enterprise }\end{array}$ & \\
\hline & B & Financing Expenditure & 165,100 \\
\hline & & 1 Establishment of Reserve Fund & 75,000 \\
\hline & & $\begin{array}{l}2 \text { Regional government } \\
\text { investment }\end{array}$ & 90,100 \\
\hline & C & Net Financing (IIIA-IIIB) & $1,185,298$ \\
\hline & D & Surplus (Deficit) (I-II) & $(492,019)$ \\
\hline & $\mathrm{E}$ & $\begin{array}{l}\text { Budget surplus of this year } \\
\text { (IIIC+IIID) }\end{array}$ & 693,279 \\
\hline
\end{tabular}

Source: Processed from Bogor District APBD of 2016 (BPKAD Kabupaten Bogor, 2016, pp. 53-55)

that are sourced from local own revenues (Shah, 1994, p. 43; Slack, 2017, p. 1). Whereas Vo (2008, p. 60) stated that the core issue in fiscal autonomy is centered on the relationship between sub-national government own revenues and expenditures.

The general phenomenon of local autonomy management in Indonesia is low local fiscal autonomy, due to the low contribution of local own revenue to total local revenue. This can be seen in the Provincial and Regency/City APBD profiles throughout Indonesia of 2014 and 2015. The average contribution to total local revenue is $24.11 \%$; while transfer funds is $55.92 \%$; and other legal local revenues is $19.97 \%$ (Ministry of Home Affairs, 2016). The low ratio of local own revenue to total local revenue reflects the low local fiscal autonomy. This is in accordance with the five categories of local fiscal autonomy determined by the Government of Australia (2008, p. xxii), namely: (a) very low (1\%-10\%); (b) low (11\%-49\%); (c) 
medium (50\%-75\%); (d) high (76\%-90\%); and (e) very high (91\%-100\%). This has implications for the high local financial dependence on fiscal transfers to finance local autonomy management.

According to Malixi (2008, p. 48) that a dependency relationship exists when the local government units source most of their income externally (through national government transfers), in order to meet their expenditure requirements. Local financial dependence on fiscal transfer is strengthened by the high use of local budget for personnel expenditure, thereby reducing the discretion of local government authority to finance local priority programs. According to Surbakti (2013, p. 24) that based on the results of the FITRA study, as many as 214 local governments spent more than 50\% of personnel expenditure from the APBD, and around $14 \%$ of these 214 local governments spent more than $70 \%$ of personnel expenditure on the APBD.

Low local fiscal autonomy also occurs in Bogor Regency of West Java Province. This can be seen in the profile of Bogor Regency APBD of 2016 as presented in Table 1.

Data in Table 1 shows that the local fiscal autonomy of Bogor Regency is low, due to the low ratio of local own revenue (38.37\%) and other legal local revenue (1.43\%), so that there is still high local financial dependence on fiscal transfer (60.20\%). Therefore, the Bogor Regency government must raise local own revenue as a reflection of local fiscal autonomy to finance local autonomy management.

Some authors state that there are two main factors that affect the low local fiscal autonomy, namely: (1) Inaccurate fiscal decentralization implementation, because the central government prioritizes the expenditure approach rather than revenue approach (Schneider, 2003, p. 27; Smith, 2012, p. 259); and (2) Ineffective local own revenue sources management by the local government (Poesoro, 2015, p. 5; J. Rodden et al., 2003, p. 13).

Prioritizing the expenditure approach in fiscal decentralization implementation in Indonesia was stated by the Ministry of Finance (2014, p. 21) that fiscal decentralization in Indonesia basically emphasizes expenditure assignment, which is characterized by the division of functions at various levels of government. Fiscal decentralization policy which prioritizes the expenditure approach was criticized by Jaweng (2010, p. 513) that the degree of local fiscal autonomy is clearly not only measured by the discretion that local governments have to spend the existing budget (the fiscal decentralization model of the expenditure side), but also the level of contribution of the local own revenue to the formation of the total existing budget (the fiscal decentralization model of the revenue side). A number of study results show that prioritizing the fiscal decentralization implementation on the expenditure approach does not have a positive impact on raising local fiscal autonomy (Fjeldstad \& Heggstad, 2012, p. 7; Smith, 2012, p. 259). On the other hand, if fiscal decentralization implementation prioritizes the revenue approach, then the local government has a discretion of authority to raise local own revenue, so as to raise local fiscal autonomy (Martinez-Vazquez, 2011, p. 5; Vallés \& Zárate, 2012, p. 63).

To raise local fiscal autonomy, it requires not only the accuracy of fiscal decentralization implementation by the central government, but also the effectiveness of local own revenue management by the local government. According to J. Rodden et al. (2003, p. 13) that the ability to respond to local needs must be met by raising local own revenues rather than relying heavily on central transfers (transfer dependency). Whereas Ahmad (1999, p. 262) stated that establishing greater fiscal autonomy for local authorities is an important consideration of the central government. Regarding the importance of the effectiveness of local own revenue sources management, Ministry of Finance (2014, p. 23) stated that APBD data in 2014 showed that in aggregate the average composition of transfer funds in local revenue reached $81.6 \%$. This phenomenon needs to be examined, because if it is seen based on available data, the economic potential of the region to develop local own revenues is still quite large, but these potentials cannot be utilized properly. Therefore, local government efforts to raise local fiscal autonomy can be done through raising all sources of local own revenue but can also be focused on sources of certain local own revenue, especially through raising local tax revenue. The importance of increasing local tax revenue because although it contributes high to the local own revenue at $73.13 \%$ in the Provincial and Regency/City APBD throughout Indonesia in 2015 (Ministry of Home Affairs, 2016), but the performance of local tax collection or local tax ratios of Provincial and Regency/City throughout Indonesia in 2014 is still low at $1.19 \%$ (Ministry of Finance, 2014, p. 25). Ideally, the local tax ratio is close to $10 \%$ as DKI Jakarta in 2013 of 9.4\% (Ministry of Finance, 2013, p. 24), because indirect local taxes related to GDRP are set at a tax rate of $10 \%$ and some are even above $10 \%$ (such as 35\% tax rate of entertainment tax and 25\% tax rate of advertisement tax).

There are two types of local tax, namely direct local tax and indirect local tax. Considering that management system of indirect local tax is more complex than direct local tax, this study focuses on indirect local tax management. In the indirect local tax management, taxpayers have more potential for tax avoidance and tax evasion, because each taxpayer 
must have an accounting of tax payment by tax subjects to be audited by the tax apparatus, so that indirect local taxpayers tend to be less compliant in paying the amount of tax owed.

The study analyzed the effects of fiscal decentralization implementation and indirect local tax management on local fiscal autonomy. There are three research questions that are going to be examine, namely: (a) Why has fiscal decentralization implementation not yet raised local fiscal autonomy in the local autonomy management in Bogor Regency? (b) Why has indirect local tax management not yet raised local fiscal autonomy in the local autonomy management in Bogor Regency? and (c) What is the prospect of raising local fiscal autonomy in the local autonomy management in Bogor Regency?

\section{METHOD}

This research used descriptive method, which will explain the phenomenon of the research object according to the data analysis results. In line with descriptive methods, this research uses qualitative approach, which will analyze qualitative data (pure qualitative data and qualitative interpretation of numerical data). According to Kountur (2004, p. $37)$ that qualitative research is research in which data is qualitative data, that generally in the form of narratives or images. It may be that in qualitative research there is data in the form of numbers, but that is only to explain something.

The object of this study is the effects of fiscal decentralization implementation and indirect local tax management on local autonomy management in Bogor Regency. To analyze fiscal decentralization implementation, four indicators are used, namely: (a) The assignment of expenditure responsibilities to local government; (b) The assignment of tax and revenue sources to local government; (c) Inter-governmental fiscal transfers; and (d) Local borrowing (Mahuni, 2008, pp. 29-30; Smith, 2012, p. 45; UNDP, 2005, p. 3). To analyze indirect local tax management, three indicators are used, namely: (a) Regional economic growth as a potential for indirect local tax revenue; (b) The ability of the local tax apparatus; and (c) The obedience of the indirect local taxpayer (Bărbuță-Mişu, 2011, p. 75; Lerche, 1980, pp. 47-50; Prichard, 2010, pp. 12-13). Whereas to analyze local fiscal autonomy, three indicators are used, namely: (a) Local financial dependence on fiscal transfer; (b) Local financial autonomy; and (c) Local expenditure discretion (Beer-Tóth, 2009, p. 70; Uchimura \& Suzuki, 2009, pp. 8-9).

To analyze the research object, primary and secondary data were collected. Primary data collection techniques are observation, interview, and focus group discussion (FGD). While secondary data collection uses documentation studies. Observation focused on the ability of the local tax apparatus (when conducting socialization of hotel tax and restaurant tax, and collecting hotel tax and restaurant tax), and the obedience of the indirect local taxpayers (when paying hotel tax and restaurant tax to local government office). The informants of interview are eight persons, namely six officials of the Bogor Regency government (DPRD Chairman; Local Secretary; Head of Local Financial Management Agency; Head of Local Revenue Management Agency; Head of Local Tax Division; and Head of Local Tax Unit in the sub-district), and two hotel managers (hotel taxpayers and restaurant taxpayers). The informants of FGD are ten officials at the Local Revenue Management Agency (Head of Local Tax Division; four Heads of Subdivision; three local tax auditors; and two Heads of Local Tax Unit).

The research was conducted in ten months, namely: (1) Secondary data collection in March to April 2016 and May to June 2017; (2) Observations in August and November 2017; (3) Interview in February and July 2018; and (4) Confirmation of the data through interview in November 2018 and FGD in January 2019.

To test the validity of qualitative data, triangulation techniques are used. Any data obtained is rechecked with other sources of information through interview and FGD. Through triangulation, valid and reliable data can be obtained, which are then analyzed for the formulation of study findings.

Specifically, for numerical data, to analyze three indicators of local fiscal autonomy, namely local financial dependence on fiscal transfer (LFDFT), local financial autonomy (LFA), and local expenditure discretion (LED), the formulas are used:

(1) $\mathrm{LFDFT}=\sum \mathrm{FT} / \sum \mathrm{TLR}$

LFDFT measures the ratio of fiscal transfer to total local revenue.

(2) $\mathrm{LFA}=\sum \mathrm{LOR} / \mathrm{TLE}$

LFA measures the ratio of local own revenue to total local expenditure.

(3) $\mathrm{LED}=\sum \mathrm{LGR} / \sum \mathrm{TLR}$

LED measures the ratio of local general revenues to total local revenue.

To analyze the potential of indirect local tax revenue, econometric analysis is used to calculate three indicators, namely local taxable capacity (LTC), local tax effort (LTE), and potential to raise local tax revenue (PRLTR). According to Le et al. (2012, p. 3 ) that taxable capacity refers to the predicted tax gross domestic product, and tax effort is defined as 
an index of the ratio between the share of the actual tax collection in gross domestic product and the predicted taxable capacity. The formula for calculating these three indicators are:

(1) $\mathrm{LTC}=$ ILTR $\times \sum \mathrm{GRDP}$

LTC amount is calculated from the indirect local tax rate multiplied by the value of the GRDP in certain sector.

(2) LTE $=\sum$ RILTR $/ \sum$ LTC

LTE ratio is calculated from the amount realization of indirect local tax revenue divided by the amount of local taxable capacity.

(3) PRLTR = LTC - LTE

PRLTR ratio is calculated from the ratio of LTC $(100 \%)$ minus the ratio of LTE.

Econometric model to estimate the potential of indirect local tax revenue:

PRLTR $=$ LTC $\left(\right.$ ILTR $\times \sum$ GRDP $)-$ LTE $\left(\sum\right.$ RILTR $/ \sum$ LTC $)$

Data processing and analysis are carried out through three stages, namely: (a) data collection and review; (b) data categorization and presentation; and (c) data analysis and conclusion.

\section{RESULTS AND DISCUSSION}

\section{A. Fiscal Decentralization Implementation}

The study results showed that the fiscal decentralization implementation has not been accurate, so it has not yet raised local fiscal autonomy.

Table 2.

Ratio of Budget Allocation for The Implementation of Regional Government Functions Based on The Bogor District APBD of 2017

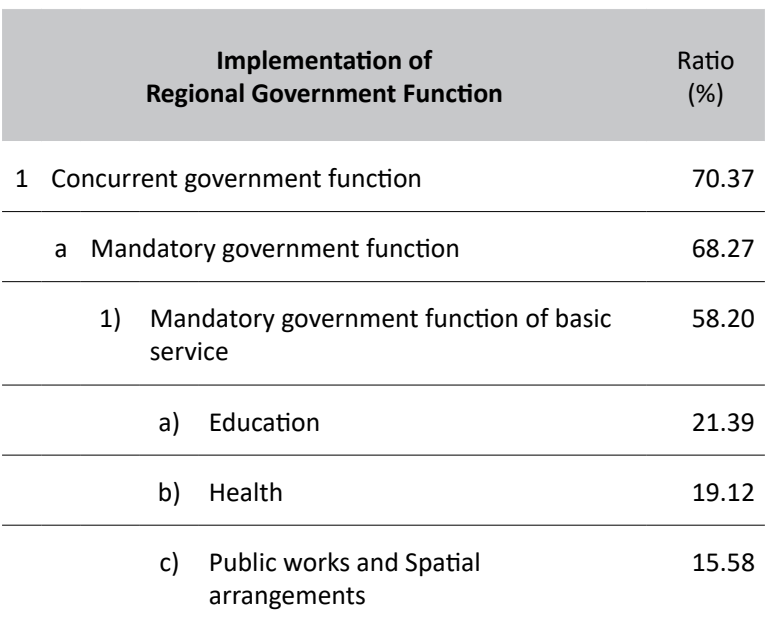

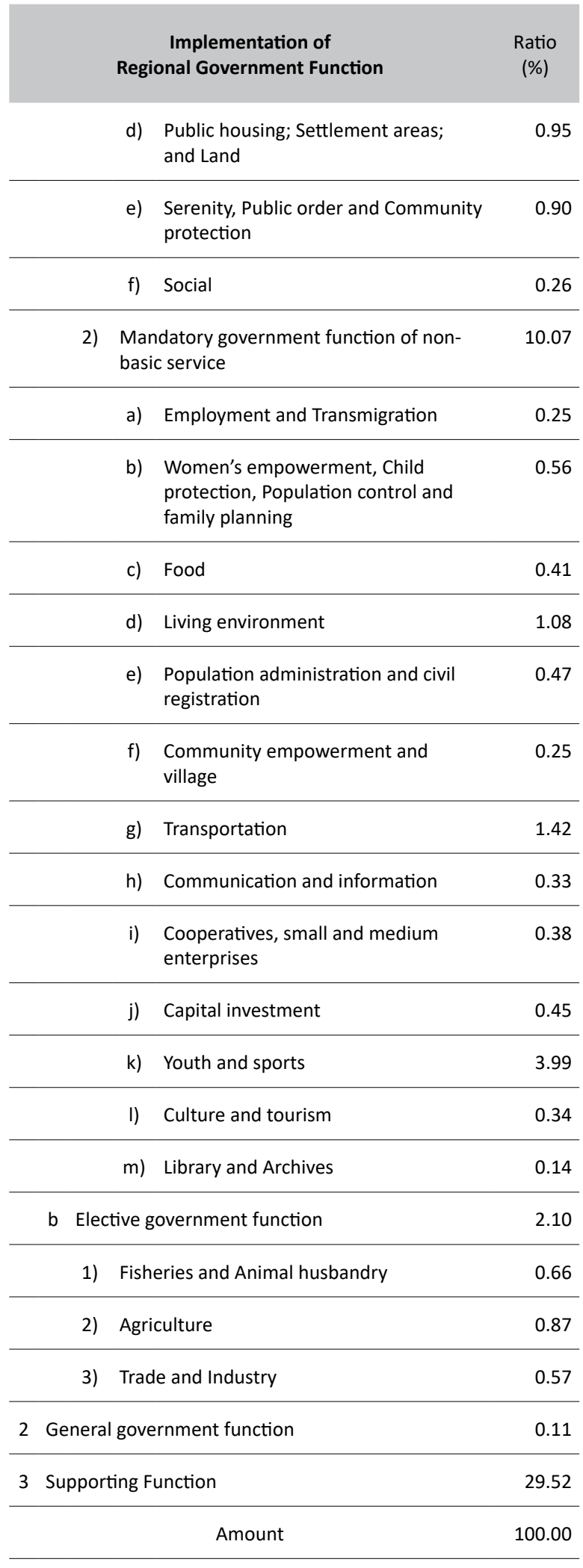

Source: Processed from Bogor District APBD of 2017 (BPKAD Kabupaten Bogor, 2017, pp. 48-50) 
This can be seen from the following four indicators.

\section{1) The Assignment of Expenditure Responsibilities to Local Government}

To analyze the assignment of expenditure responsibilities to local government, the main question is "What are the functions and expenditure responsibilities of each level of government?" (UNDP, 2005, p. 3). The expenditure responsibility of each level of government is the responsibility of each level of government to finance the management of government affairs which become its authority. The expenditure responsibility of local government is the responsibility of local government in financing the implementation of government affairs which are the local authority.

The study results showed that the assignment of expenditure responsibilities to local governments is too much. This can be seen from the too many concurrent government functions as regency/city authority that is not commensurate with the local fiscal autonomy, so the implementation of several local authority is less effective. Based on Law No. 23 of 2014 on Local Government, there are thirty-two concurrent government functions that constitute regional authority, consisting of twenty-four mandatory government functions and eight elective government functions. The fact shows that the Bogor Regency government only carries out twenty-nine and a half concurrent government functions, because three and a half elective government functions are the authority of the province government (energy and mineral resources; forestry; and marine, except fisheries).

The effectiveness of local authority implementation based on local government expenditure responsibility can be seen from the profile of the local budget allocation for each concurrent government functions. In this case, four categories of effectiveness in implementing local authority based on the budget allocation ratio will be determined, namely: (a) Very Effective $(10 \%$ or more); (b) Effective (0.25\% to 9.99\%); (c) Fairly Effective (under 0.25\%); and (c) Ineffective (no special organization was formed and no special budget was allocated in the APBD). To find out the effectiveness of concurrent government functions implementation by the Bogor Regency government, it can be seen from the ratio of local budget allocations as presented in Table 2.

Based on the ratio of budget allocations for each concurrent government functions presented in Table 2, it can be determined four categories of effectiveness of concurrent government functions implementation by the Bogor Regency government, namely: (a) Very Effective in three concurrent government functions (education; health; public works and spatial arrangements); (b) Effective in fifteen and a half concurrent government functions; (c) Fairly Effective in five concurrent government functions; and (d) Not Effective in seven concurrent government functions. The study findings that there are six concurrent government functions that are not carried out effectively are the implications of the too high of local government expenditure responsibility compared to local fiscal autonomy.

In accordance with the findings of this study, it is suggested that the decentralization of concurrent government functions to autonomous regions, needs to consider the following matters: (a) Decentralization of the number of concurrent government functions as a form of the assignment of expenditure responsibilities to local governments must be commensurate with the local fiscal autonomy, so that it does not have implications for the high local fiscal gap which will financed through transfer funds from the central government; (b) Decentralization of concurrent government functions to local government must carefully consider the externalities principle, so that if the implementation of certain concurrent government function is ineffective by the regency/city government, it can be transferred to the authority of the provincial or central government; (c) To ensure the amount of local fiscal needs in financing the implementation of mandatory government functions of basic services, the central government needs to set specific block grant for each local government using the Standard Spending Assessment (SSA) method. In the context of using the SSA method, each related ministry must develop a minimum service standards policy for the implementation of each mandatory government functions of basic services.

\section{2) The Assignment of Taxes and Revenue Sources to Local Government}

To analyze the assignment of taxes and revenue sources to local government, the main question is "Once sub-national governments are assigned certain expenditure responsibilities, which tax or non-tax revenue sources will be made available to sub-national governments in order to meet those responsibilities?" (UNDP, 2005, p. 3). Therefore, it is necessary to analyze the composition of local own revenue and their contribution to total local revenue (as local fiscal autonomy) and to total local expenditure (as local financial autonomy). The study results showed that the assignment of taxes and revenue sources to local government has not raised local taxing power to raise local own revenue, so that local fiscal autonomy and local financial autonomy is still low. 
The fiscal decentralization implementation on the revenue side (the assignment of taxes and revenue sources to local government) is a central government policy regulated in Law No. 28 of 2009 on Local Taxes and Local Levies. Data in Table 1 shows that the largest contribution of local own revenue comes from local taxes revenue. This is the implication of the policy change in Law No. 28 of 2009 (substitute of Law No. 34 of 2000), namely: (a) Submission of two types of central tax into regency/city tax, namely the Land and Building Rights Acquisition Fees and Property Tax (rural and urban areas); and (b) Adding the types of regency/city taxes, from seven types (stipulated in Law No. 34 of 2000) to eleven types (stipulated in Law No. 28 of 2009).

In order to raise local tax revenue, so as to raise local fiscal autonomy, the central government must increase local taxing power of regency/city government, which can be done through: (a) The central government submits central tax to regency/ city tax; (b) The central government must add local tax objects and local tax rates of regency/city taxes; (c) The central government must increase the discretion of authority of the regency/city government in the collection of local levies (such as the addition of types and objects of business service levies).

To increase local fiscal autonomy, the role of regency/city government is needed, namely: (a) Increasing the intensification of direct local tax collection which has a large potential revenue through increasing the role of local tax apparatus in collecting direct local taxes (such as Land and Building Rights Acquisition Fees and Property Tax); (b) Increasing the intensification of indirect local tax collection, through audit investigation of the financial reports of indirect local taxpayers to prevent tax avoidance or tax evasion by indirect local taxpayers; (c) Local governments can add new types of local businesses to add objects of Business Service Levies, which can be utilized by the community through payment of business service levies, so as to an increase local own revenue; (d) Encourage innovation of Local Owned Enterprises to increase profits, so that there will be an increase in dividends paid to the local government as local own revenue.

\section{3) Intergovernmental Fiscal Transfers}

If the assignment of local expenditure responsibilities (the first form of fiscal decentralization on the expenditure side) is not commensurate with the assignment of local taxes and other sources of revenue as local own revenue (the second form of fiscal decentralization on the revenue side), there will be local fiscal gap. To reduce the local fiscal gap, the central government established a policy of transfer funds to local governments (the third form of fiscal decentralization). Determination of transfer funds from the central government to the local government is in addition for sources of local revenue. This was stated by UNDP (2005, p. 3 ) that "In addition to assigning revenue sources, central governments may provide regional and local governments with additional resources through a system of intergovernmental fiscal transfers or grants". The transfer funds are not allocated to the local government whose local fiscal autonomy commensurate with the local government expenditure responsibilities. The study of fiscal transfer to local governments aims to find out the contribution of transfer funds to total local revenue (to find out local financial dependence on fiscal transfer) and to total local expenditure (to find out local fiscal gaps).

Data in Table 1 showed that the contribution of fiscal transfer to total local revenue is $62.20 \%$ and to total local expenditure is $55.61 \%$. The data has meaning: (a) The high contribution of transfer funds to total local revenue reflects the high local financial dependence on fiscal transfers, so that to raise total local revenue is very dependent on fiscal transfers; (c) The high contribution of transfer funds to total local expenditure reflects high local fiscal gap, so that fulfillment of local government expenditure responsibilities is very dependent on fiscal transfer.

To reduce local financial dependence on fiscal transfers, the central government must establish policies to increase local fiscal autonomy. This policy is focused on increasing local taxing power, especially the assignment of taxes and revenue sources to local government.

\section{4) Local Borrowing}

If the local government expenditure responsibilities to finance local governmental functions (the first form of fiscal decentralization on the expenditure side) cannot be financed from tax and other revenue sources as local own revenue (the second form of fiscal decentralization on the revenue side) plus transfers fund from the central government (the third form of fiscal decentralization on the revenue side), then the local government can carry out local borrowing (the fourth form of fiscal decentralization on the revenue side). The study results showed that the Bogor Regency government do not carry out local borrowing. This fact means that the local government of Bogor Regency does not face local budget constraints, despite the low local fiscal autonomy.

Based on the study results on four indicators, it can be stated that the fiscal decentralization implementation has not been accurate, so it has not yet raised local fiscal autonomy in the local autonomy management of Bogor Regency. This is due to the 
fiscal decentralization implementation by the central government prioritizing the expenditure approach rather than the revenue approach, so that local own revenues are not commensurate with the expenditure responsibilities of local government.

\section{B. Indirect Local Tax Management}

The study results showed that indirect local tax management is not yet effective, so it has not yet raised local fiscal autonomy. This can be seen from the following three indicators.

\section{1) Regional Economic Growth as Potential of Indirect Local Tax Revenue}

There are two methods of calculating the potential of local tax revenue based on regional economic growth, namely: (a) Total Taxable Resources (TTR) as a method of calculating local tax revenue potential based on the GRDP value; and (b) Representative Tax System (RTS) as method for calculating local tax revenue potential based on per capita income (Dafflon, 2007, p. 376). This study uses the TTR method. According to Sukirno (1981, p. 73) that "Calculation of local tax revenue potential based on the GRDP value is based on the amount of local tax rate multiplied by the GRDP value in the related sectors".

The potential of indirect local tax revenue will be analyzed based on the GRDP value in certain business fields, because entrepreneurs are taxpayers of indirect local tax. However, this study only calculates sample data on the Business Fields in the Provision of Accommodation and Food Beverage which is a hotel taxpayer and restaurant taxpayer, because hotel tax and restaurant tax is an indirect local tax used as a sample of the object of this study. Three main indicators can be analyzed, namely: (a) Local

\section{Table 3.}

Regional Taxable Capacity (LTC), Regional Tax Effort (LTE), and Potential to Raise Regional Tax Revenue (PRLTR) of Hotel Tax and Restaurant Tax as Indirect Regional Tax in Bogor District of 2016

\begin{tabular}{ccccc}
$\begin{array}{c}\text { GRDP on Provision } \\
\text { of Accommodation } \\
\text { and Food Beverage } \\
\text { (millions) }\end{array}$ & $\begin{array}{c}\text { LTC } \\
\text { (millions) }\end{array}$ & $\begin{array}{c}\text { Indirect } \\
\text { Regional } \\
\text { Tax } \\
\text { Revenue } \\
\text { (millions) }\end{array}$ & $\begin{array}{c}\text { Ratio } \\
\text { of } \\
\text { LTE } \\
\text { (\%) }\end{array}$ & $\begin{array}{c}\text { Ratio } \\
\text { of } \\
\text { PRLTR } \\
\text { (\%) }\end{array}$ \\
\hline 1 & $\mathbf{2}$ & $\mathbf{3}$ & $\mathbf{4}$ & $\mathbf{5}$ \\
\hline $4,822,746$ & 482,274 & 146,069 & 30.29 & 69.71 \\
\hline
\end{tabular}

Source: Processed from Bogor District in Figures of 2017 (BPS Kabupaten Bogor, 2017, p. 250) and Bogor District APBD of 2017 (BPKAD Kabupaten Bogor, 2016, p. 53) taxable capacity (LTC); (b) Local tax effort (LTE); and (c) Potential to raise local tax revenue (PRLTR). To calculate the LTC, the hotel tax rate and restaurant tax rate of $10 \%$ are used according to the law number 28 of 2009.

Based on the data of GRDP value and indirect local tax revenue of the Bogor Regency of 2016, the calculation results as presented in Table 3 .

Data in Table 3 showed that: (a) LTC is Rp482,274,000,000; (b) LTE is 30.29\%; and (c) PRLTR is $69.71 \%$. The high potential of indirect local tax revenue that has not been effectively managed by the Bogor Regency government, is due to the low determination of its revenue targets that have not been based on econometric analysis of the value of GRDP.

\section{2) The Ability of the Local Tax Apparatus}

To analyze the ability of the local tax apparatus, three sub-indicators are used, namely conceptual ability, human ability, and technical ability. Collection of data about the ability of the local tax apparatus using the method of focus group discussions and indepth interviews with local official and local taxpayer. The results showed that the ability of the local tax apparatus was at a high enough level. This means that the ability of the local tax apparatus is not optimal in supporting the effectiveness of indirect local tax management.

\section{3) The Obedience of the Indirect Local Taxpayer}

To analyze the obedience of the indirect local taxpayer, three sub-indicators are used, namely taxpayer consciousness, taxpayer compromise, and taxpayer compliance. Collection of data about the obedience of the indirect local taxpayer using the method of focus group discussions and in-depth interviews with local official and local taxpayer. The results showed that the obedience of the indirect local taxpayer is at a high enough level. This means that the obedience of the indirect local taxpayer is not optimal in supporting the effectiveness of indirect local tax management.

Based on the study results on three indicators, it can be stated that indirect local tax management is not yet effective, so it has not yet raised local fiscal autonomy of Bogor Regency. This is due to the low determination of indirect local tax revenue targets that have not been based on econometric analysis of regional economic growth, the ability of the local tax apparatus is not optimal, and the obedience of indirect local taxpayer is not optimal. This finding is in accordance with the results of research by BărbuțăMişu (2011, p. 75) that economic factors (analysis of regional economic growth) and non-economic factors (the ability of local tax apparatus and the obedience 
of local taxpayers) are determinants of raising local tax revenue.

\section{The Prospect of Raising Local Fiscal Autonomy}

Data in Table 1 shows that the ratio of local fiscal autonomy is $38.37 \%$. This means that the local fiscal autonomy of Bogor Regency is low category. This fact has implications for the following three indicators.

\section{1) Local Financial Dependence on Fiscal Transfer}

Local financial dependence on fiscal transfer exists when the local government units' source most of their income externally, i.e. through national government transfers, in order to meet their expenditure requirements. Local financial dependence on fiscal transfer is measured by the ratio of total fiscal transfer to total local revenue. Data in Table 1 shows that the ratio of local financial dependence on fiscal transfer is $60.20 \%$. This means that the Bogor Regency financial dependence on fiscal transfers is high category.

\section{2) Local Financial Autonomy}

Local financial autonomy is the right and the ability of local governments to manage local revenues and expenditures and modulate the local budget constraint. Local financial autonomy measures the ratio of local own revenue to total local expenditure. Data in Table 1 shows that the ratio of local financial autonomy is $43.47 \%$. This means that local financial autonomy of Bogor Regency is low category.

\section{3) Local Expenditure Discretion}

Local expenditure discretion is the independence of authority of local governments in decision making to use local revenue in financing local government expenditure responsibilities. Local expenditure discretion is measured by the ratio of local general revenue (local own revenue plus tax-sharing funds, plus general allocation funds) minus non-discretion expenditure (such as personnel expenditure, interest expenditure, and others), and then divided by total local revenue. Based on the data in Table 1 shows that the ratio of local expenditure discretion is $44.13 \%$. This means that local expenditure discretion of Bogor Regency is limited category.

Based on the study results on three indicators, the local government must raise local fiscal autonomy. This is reflected in the high local financial dependence on fiscal transfer, low local financial autonomy, and limited local expenditure discretion.

The prospect of raising local fiscal autonomy is determined by the accuracy of the fiscal decentralization implementation and the effectiveness of indirect local tax management. The accuracy of fiscal decentralization implementation requires the central government policy in the assignment of taxes and revenue sources to local government must be commensurate with the assignment of expenditure responsibilities to local government. The effectiveness of indirect local tax management requires that local government efforts to increase indirect local tax revenues must precisely determine the increase of revenue targets according to the results of econometric analysis of GDRP on certain sectors, improving the ability of local tax apparatus, and improving the obedience of indirect local taxpayer.

\section{Conclusion}

Based on the analysis results, the study concludes that: (1) Fiscal decentralization implementation has not been accurate, so it has not yet raised local fiscal autonomy. This is due to the fiscal decentralization implementation by the central government prioritizing the expenditure approach rather than the revenue approach, so that local own revenues is not commensurate with the expenditure responsibilities of local government; (2) Indirect local tax management has not been effective, so it has not yet raised local fiscal autonomy. This is due to the low determination of indirect local tax revenue targets that have not been based on econometric analysis of regional economic growth, the ability of the local tax apparatus is not optimal, and the obedience of indirect local taxpayer is not optimal; and (3) The prospect of raising local fiscal autonomy is determined by the accuracy of fiscal decentralization implementation by the central government and the effectiveness of indirect local tax management by the local governments.

The new findings of this study as novelty are: (1) The study of fiscal decentralization implementation in relation to local fiscal autonomy:(a) Local borrowing is not the main indicator of the fiscal decentralization implementation variable; and (b) New indicators need to be added, such as local tax autonomy; and (2) The study of indirect local tax management in relation to local fiscal autonomy:(a) Regional economic growth is the main indicator of the indirect local tax management variable; and (b) New indicators need to be added, such as the use of information and communication technology by indirect local taxpayers; and law enforcement against indirect local taxpayers.

Based on the study results, suggestions are given, namely: (1) Academic suggestions for strengthening empirical findings, further studies with the same object in another locations need to be carried out; 
and (2) Practical suggestions for raising local fiscal autonomy: (a) the accuracy of fiscal decentralization implementation requires the central government policy in the assignment of taxes and revenue sources to local government must be commensurate with the assignment of expenditure responsibilities to local government; and (b) the effectiveness of indirect local tax management requires that the efforts of local governments to increase indirect local tax revenues must precisely determine the increase of revenue targets according to the results of econometric analysis of the GRDP value, improving the ability of local tax apparatus, and improving the obedience of indirect local taxpayer.

\section{ACKNOWLEDGMENT}

I would like to thank and give the highest appreciation to Prof. Dr. H. Utang Suwaryo, Prof. Dr. Samugyo Ibnu Redjo, MA, and Dr. Yadi Supriyadi, DEA as a dissertation promoter and co-promoter. I would also like to thank all the lecturers and dissertation examiners for their knowledge and counsels. I express my gratitude to the Bogor Regency local government where the research was conducted.

The dissertation can be presented as a scientific article published in this journal. I would also like to thank for the constructive comments from the reviewers. I am responsible for all errors in this paper. The entire bibliography has been rechecked.

\section{REFERENCES}

Ahmad, J. K. (1999). South Africa: an intergovernmental fiscal system in transition. In R. M. Bird \& F. Vaillancourt (Eds.), Fiscal Decentralization in Developing Countries (pp. 239-270). Cambridge University Press. https:// doi.org/10.1017/CB09780511559815.009

Bărbuţă-Mișu, N. (2011). A Review of Factors for Tax Compliance. Economics and Applied Informatics, 17(1), 69-76. http://www.eia.feaa.ugal.ro/ images/eia/2011-1/Nicoleta_BarbutaMisu.pdf

Beer-Tóth, K. (2009). Local Financial Autonomy in Theory and Practice: The Impact of Fiscal Decentralisation in Hungary [University of Fribourg Switzerland]. https://doc.rero.ch/ record/12729/files/Beer-TothK.pdf

BPKAD Kabupaten Bogor. (2016). APBD Kabupaten Bogor Tahun 2016.

BPKAD Kabupaten Bogor. (2017). APBD Kabupaten Bogor Tahun 2017.

BPS Kabupaten Bogor. (2017). Bogor Regency In Figures.

Dafflon, B. (2007). Fiscal Capacity Equalization in Horizontal Fiscal Equalization Programs. In R.
Boadway \& A. Shah (Eds.), Intergovernmental Fiscal Transfers: Pinciples and Practice (pp.361396). The World Bank.

Fjeldstad, O.-H., \& Heggstad, K. (2012). Local Government Revenue Mobilisation in Anglophone Africa. SSRN Electronic Journal, 6, 1-34. Bergen, Norway: Michelsen Institute. https://doi.org/10.2139/ssrn.2408608

Government of Australia. (2008). Assessing Local Government Revenue Raising Capacity (Productivity Commission Research Report). https://ssrn.com/abstract=1159623

Jaweng, R. E. (2010). Memperkuat Otonomi Fiskal Daerah. Analisis CSIS, 39(4), 513-533.

Kountur, R. (2004). Metode Penelitian. CV. Teruna Grafica.

Law Number 23 of 2014 on Local Government. (2014). Pub. L. No. 23 of 2014.

Law Number 28 of 2009 on Local Taxes and Local Levies. (2009). Pub.L. No. 28 of 2009.

Le, T. M., Moreno-Dodson, B., \& Bayraktar, N. (2012). Tax Capacity and Tax Effort: Extended Cross-Country Analysis from 1994 to 2009 (No. 6252). The World Bank. https://doi. org/10.1596/1813-9450-6252

Lerche, D. (1980). Efficiency of Taxation in Indonesia. Bulletin of Indonesian Economic Studies, 16(1), 34-51. https://doi.org/10.1080/0007491801 2331333689

Mahuni, F. J. R. (2008). The Efficiency of a Fiscally Decentralized Government in The Provision of Social Services: The Case of The Eastern Cape Provincial Government in South Africa. University of Fort Hare.

Malixi, C. (2008). Review and Assessment of Decentralization in the Philippines Focusing on Local Resource Mobilization (1991-2001). University of Freiburg.

Martinez-Vazquez, J. (2011). The Impact of Fiscal Decentralization: Issues in Theory and Challenges in Practice. Metro Manila, Philippines: Asian Development Bank. http://hdl.handle. net/11540/966

Ministry of Finance. (2013). Deskripsi dan Analisis APBD 2013.

Ministry of Finance. (2014). Deskripsi dan Analisis APBD 2014.

Ministry of Home Affairs. (2016). Profil APBD Provinsi dan Kabupaten/Kota Seluruh Indonesia Tahun 2014 dan Tahun 2015.

Poesoro, A. A. L. (2015). Fiscal Decentralization and Sub-national Taxes: Specific Case of Indonesia (No. 1015; Tax Law Design and Policy Series). https://ddtc.co.id/research/publications/ working-paper/fiscal-decentralization-and- 
sub-national-taxes-specific-case-of-indonesia/

Prichard, W. (2010). Taxation and State Building: Towards a Governance Focused Tax Reform Agenda. IDS Working Papers, 2010(341), 01-55. https://doi.org/10.1111/j.20400209.2010.00341_2.x

Rodden, J., Eskeland, G. S., \& Litvack, J. (2003). Fiscal Decentralization and the Challenge of Hard Budget Constraints (J. A. Rodden, G. S. Eskeland, \& J. Litvack (Eds.)). The MIT Press. https://doi. org/10.7551/mitpress/3021.001.0001

Schneider, A. (2003). Who Gets What from Whom? The Impact of Decentralisation on Tax Capacity and Pro-Poor Policy (No. 179; IDS Working Papers). https://opendocs.ids.ac.uk/opendocs/ handle/20.500.12413/3970

Shah, A. (1994). The reform of intergovernmental fiscal relations in developing and emerging market economies. The World Bank. https://doi. org/10.1596/0-8213-2836-0

Slack, E. (2017). How Much Local Fiscal Autonomy Do Cities Have? A Comparison of Eight Cities around the World. In IMFG Perspectives. IMFG, Munk School of Global Affairs, University of Toronto.

Smith, H. J. M. (2012). Fiscal Decentralization and Development: An Analysis of City Governments in Argentina and Mexico, 1980-2010 [Florida International University]. In FIU Electronic Theses and Dissertation. https:// digitalcommons.fiu.edu/etd/613
Sukirno, S. (1981). Pengantar Teori Ekonomi Makro. Fakultas Ekonomi Univeritas Indonesia.

Surbakti, R. (2013). Berbagai Aspek Kebijakan Otonomi Daerah. Jurnal Ilmu Pemerintahan, 43, 1-35.

Suwandi, M. (2002). Konsepsi Dasar Otonomi Daerah Indonesia.

Treisman, D. (2007). The Architecture of Government: Rethinking Political Decentralization. Cambridge University Press.

Uchimura, H., \& Suzuki, Y. (2009). Measuring Fiscal Decentralization in the Philippines (IDE Discussion Paper, Vol. 209). hdl.handle. net/2344/854

UNDP. (2005). Fiscal Decentralisation and Poverty Reduction. UNDP. https://www.undp.org/ content/undp/en/home/librarypage/povertyreduction/fiscal-decentralization-and-povertyreduction.html

Vallés, J., \& Zárate, A. (2012). Fiscal devolution and green tax administration. Urban Public Economics Review, 16, 60-92. https://www. redalyc.org/articulo.oa?id=50424589003

Vo, D. H. (2008). The Economics of Measuring Fiscal Decentralisation. Part II: New Fiscal Decentralisation Indices (No. 08-14; Economics Discussion/Working Papers). https:// www.celt.uwa.edu.au/_data/assets/pdf_ file/0010/94267/08_14_Vo.pdf 